\title{
Mating system in Myracrodruon urundeuva (Anarcadiaceae): implications for conservation genetics ${ }^{1}$
}

\author{
ANA PAULA SILVA CAMPOS GAINO2,5, MARIO LUIZ TEIXEIRA DE MORAES ${ }^{3}$, \\ JULIANA PRADO MOREIRA ${ }^{2}$, LAILA TONIOL CARDIN ${ }^{2}$, MARCELA APARECIDA MORAES ${ }^{2}$, \\ ALEXANDRE MARQUES DA SILVA², MIGUEL LUIZ MENEZES FREITAS ${ }^{3}$ and \\ ALEXANDRE MAGNO SEBBENN ${ }^{4}$
}

(received: January 13, 2011; accepted: November 11, 2011)

\begin{abstract}
Mating system in Myracrodruon urundeuva (Anarcadiaceae): implications for conservation genetics. The aims of this study were to investigate the mating system of a fragmented population of the dioecious tropical tree Myracrodruon urundeuva Allemão, using five microsatellite loci and the mixed mating and correlated mating models. The study was conducted in the Estação Ecológica de Paulo de Farias (436 ha), where the population occupies about 142 ha. The mating system was estimated using 514 open-pollinated offspring, collected from 30 seed-trees. Estimates of the multilocus outcrossing rate confirm that the species is dioecious $\left(t_{m}=1.0\right)$. Low levels of mating among relatives were detected in the population $\left(1-t_{s}=0.020\right)$. The estimate of paternity correlation $\left(r_{p(m)}\right)$ indicated that offsprings were composed of mixtures of half-sibs and full-sibs, with the latter occurring at a low frequency (average of 0.148$)$. The estimated coancestry coefficient within families $(\Theta=0.147)$ was larger and the effective population size $\left(N_{e(v)}\right)$ was lower $\left(N_{e(v)}=2.98\right)$ than expected in progenies from panmictic populations $\left(\Theta=0.125, N_{e(v)}=4\right.$, respectively). In terms of conservation, the results indicate that to retain an effective population size of 150 , is necessary to collect seeds from at least 50 seed-trees.
\end{abstract}

Key words - correlated matings, fragmentation, microsatellite, variance effective population size

RESUMO - Sistema de reprodução em Myracrodruon urundeuva (Anarcadiaceae): implicações para a conservação genética. O objetivo deste estudo foi investigar o sistema de reprodução de uma população fragmentada da espécie arbórea dióica, Myracrodruon urundeuva Allemão, utilizando cinco locos microssatélites e os modelos mistos de reprodução e de cruzamentos correlacionados. O estudo foi conduzido na Estação Ecológica de Paulo de Faria (436 ha), onde a população ocupa uma área aproximada de 142 ha. Foram amostradas 514 progênies de polinização aberta coletadas de 30 árvores matrizes da população. A estimativa da taxa de cruzamento multilocus confirma que a espécie é dióica $\left(t_{m}=1,0\right)$. Baixos níveis de cruzamentos entre parentes foram detectados na população $\left(1-t_{s}=0,020\right)$. A estimativa da correlação de paternidade $\left(r_{p(m)}\right)$ indicou que as progênies são compostas por misturas de meios-irmãos e irmãos-completos, embora este último ocorra em menor proporção (média de 0,148$)$. O coeficiente de coancestria dentro das progênies $(\Theta=0,147)$ foi maior e o tamanho efetivo de variância $\left(N_{e(v)}=2,98\right)$ foi menor do que o esperado em progênies de populações panmíticas $\left(\Theta=0,125, N_{e(v)}=4\right.$, respectivamente). Em termos de conservação genética, os resultados indicam que para se obterem lotes de sementes com tamanho efetivo de referência de 150, é necessário coletar sementes de pelo menos 50 árvores matrizes.

Palavras-chave - cruzamentos correlacionados, fragmentação, microssatélites, tamanho efetivo populacional

\section{Introduction}

Understanding the mating systems of tree species is extremely important because it enables a better comprehension of patterns of gene flow, distribution of

\footnotetext{
1. Parte da tese de doutorado da primeira autora, Programa de PósGraduação em Agronomia - Genética e Melhoramento de Plantas, Universidade Estadual Paulista Júlio de Mesquita Filho - UNESP, SP, Brazil.

2. Universidade Estadual de Londrina-UEL, Caixa Postal 6001, CEP 86051-980 Londrina, PR, Brazil.

3. Universidade Estadual Paulista Júlio de Mesquita Filho - UNESP, Faculdade de Engenharia de Ilha Solteira, Av. Brasil Centro, 56, Caixa Postal 31, 15385-000 Ilha Solteira, SP, Brazil.

4. Instituto Florestal de São Paulo, Caixa Postal 1322, 01059-970 São Paulo, SP, Brazil.

5. Corresponding author: apsdecampos@yahoo.com.br
}

genetic diversity among and within populations (Bawa 1974), relatedness within open pollinated progenies and effective population size of each progeny (Sebbenn 2006). In addition, this knowledge permits us to determine the number of seed trees from which it is necessary to collect seeds, aiming to retain a minimum effective population size for ex situ conservation of the species.

The mating systems of tropical tree species is generally characterized as mixed, with a predominance of outcrossing ( $t>0.9$, Sebbenn 2006). However, a large proportion of mating is not random as mating occurs between related individuals (biparental inbreeding) and within the same tree (correlated matings), producing open pollinated progenies composed of mixtures of different degrees of relatedness, such as: i) self-sibs; ii) full-sib; iii) half-sibs; iv) self-half-sibs (Squillace 
1974, Ritland 1989). Furthermore, although tropical tree species have high rates of outcrossing, their mating systems may vary among species, populations of a species, reproductive events within a population and among flowers of the same tree; this is due to genetic and environmental influences on the mating system (Sebbenn 2006). Additionally, anthropogenic factors such as forest fragmentation and selective logging may also affect the mating systems of tropical tree species (Nason \& Hamrick 1997, Lowe et al. 2005, Lacerda et al. 2008). Forest fragmentation may alter population densities of pollinators, amplify fluctuations in pollinator populations, and modify the behavior of foraging pollinators (Pulliam 1988), potentially affecting pollination levels and seed production in plants (Jennersten 1988, Menges 1991). As a result, forest fragmentation may increase the frequency of biparental inbreeding and correlated mating. The increase of inbreeding can result in inbreeding depression, which is more severe in predominantly outcrossing species that naturally maintain high levels of deleterious genes (Nason \& Hamrick 1997).

In addition to the influence of various factors on the mating systems, tropical tree species generally have low population density $\left(<1\right.$ tree ha $\left.^{-1}\right)$ and depend on animals for pollen dispersal (Bawa 1974). From a conservation perspective, low population density is a factor that promotes the occurrence of selfing (Moraes \& Sebbenn 2011). However, selfing is offset by the large number of dioecious species (approximately 22\%, Bawa et al. 1985), self-incompatibility systems ( $86 \%$ of monoecious and hermaphrodite species have some self-incompatibility system, Bawa et al. 1985), and inbreeding depression. These three factors favor outcrossing and therefore the recombination of genes and the maintenance or increase of genetic diversity within populations. Furthermore, these factors promote low levels of genetic differentiation among populations due to extensive gene flow between populations and large reproductive neighborhood sizes (Loveless \& Hamrick 1984).

Myracrodruon urundeuva Allemão (Anarcadiaceae) is a tropical tree species widely distributed in South America (Rizzini 1995, Lorenzi 1998). In Brazil, the species is characteristically found in dense clusters in savanna regions, although it has been reported in humid forest regions as well (Lorenzi 1998). Myracrodruon urundeuva is a dioecious species (Santin \& Leitão Filho 1991), although there are reports of monoecious individuals (Nogueira et al. 1982) and the occurrence of hermaphroditism (Carvalho 1994). Pollination is performed by bees and diaspores are dispersed by anemochory (Carvalho 1994). The fruits consist of a globular or ovoid drupe with a persistent calyx, considered a fruit seed (Figueirôa et al. 2004). Like any large tree, M. urundeuva shelters a number of floral and faunal organisms under its canopy and it is considered a key species in the ecosystem. In addition to its important ecological role, the species has economic importance due to the production of excellent quality timber (high density and low deterioration), commonly used to build fences, farm and residential buildings, and furniture. Due to the high quality of the wood, natural populations of the species have to date been intensively exploited (Ribeiro 1989).

The aims of this study were to investigate the mating system of a natural population of M. urundeuva, located in the Estação Ecológica de Paulo de Farias (EEPF), using microsatellite markers and the mixed and correlated mating models. More specifically, we attempted to answer the following questions: i) Does mating among relatives occur in the EEPF population? ii) What is the proportion of correlated mating? iii) What is the coancestry coefficient and the variance effective population size within families? iv) What is the minimum number of seed trees required for seed collection, aiming to retain a sample (progeny arrays) with the effective population size of $150(3 \times 50$, Nunney $\&$ Campbell 1993)?

\section{Material and methods}

The study population is located in the Estação Ecológica de Paulo de Farias (EEPF) run by the Instituto Florestal de São Paulo. EEPF has an area of 436 ha $\left(19^{\circ} 55^{\prime}\right.$ and $19^{\circ} 58 \mathrm{~S}$ and $49^{\circ} 31^{\prime}$ and $49^{\circ} 32^{\prime} \mathrm{W}$ ), with an altitude ranging from 400 to $495 \mathrm{~m}$. According to the Koeppen classification, the climate is type Aw (tropical wet and dry) and the region is characterized by two seasons: a dry season, April to September with average rainfall of $167 \mathrm{~mm}$, and a rainy season from October to March, with an average of $978 \mathrm{~mm}$. The region where EEPF is located is a transitional zone between semi-deciduous forest and savanna. The area lies in the northern region of São Paulo, on the left bank of the Rio Grande (Red Water Dam), bordering the states of São Paulo (semi-deciduous forest) and Mato Grosso do Sul. EEPF is covered by natural vegetation with little human interference; the vegetation has a wide variety of tree species consisting of 51 plant families (Stranghetti 1996). In EEPF, M. urundeuva trees occur predominantly in the northern section, where they occupy an area of approximately $142 \mathrm{ha}$. The total number of M. urundeuva individuals in EEPF is 470 (density of 3.3 tree ha $^{-1}$ ), with 177 females, 269 males, and 24 sex-undetermined individuals (due to the absence of flowers during the evaluated reproductive event in 2008). In the last census in 2008, approximately $50 \%$ of all $M$. urundeuva trees located within 
EEPF had less than a $25 \mathrm{~cm}$ diameter at breast height (dbh), ranging from 11.03 to $94.54 \mathrm{~cm}$. The dbh of the 30 sampled seed trees ranged from 19.74 to $94.54 \mathrm{~cm}$.

For this study, 600 open-pollinated offspring (20 offspring of each seed tree) from 30 seed trees were sampled from a progeny test of $M$. urundeuva. The seeds for the progeny test were collected from EEPF in 1996. Seed trees were chosen randomly, without consideration of growth, vigor or stem form and were separated by at least $100 \mathrm{~m}$ in order to prevent seed collection from related trees. From each seed tree more than 100 fruits were collected; each $M$. urundeuva fruit has a single seed. Offspring were established in 1996 at the Education, Research and Extension Farm of FEIS/UNESP, located in the municipality of Selvíria (MS). From the 600 sampled offspring, 86 were excluded from the analysis due to missing data for two or more loci.

The protocol used for the extraction of genomic DNA from individuals of $M$. urundeuva was CTAB (Doyle \& Doyle 1990), with some modifications to the extraction buffer: (proteinase K (100 mg mL-1), PVP-40 (4\%), PVP-360 $(1 \%)$ and $\beta$ mercaptoethanol (2\%). The reaction amplification of SSR loci were conducted to evaluate five loci described for M. urundeuva in Caetano et al. (2005). Thus, the PCRs were composed of $1 \mathrm{ng}$ of genomic DNA in a final volume of $6 \mathrm{~mL}$ containing: $200 \mu \mathrm{M}$ of each dNTP, $2.5 \mathrm{mM} \mathrm{MgCl}$, $0.33 \mathrm{mM}$ of each primer, ultrapure sterile water and $1 \mathrm{x}$ Go Taq Master Mix PROMEGA. The forward component of each pair of primers was labeled with a specific fluorescence. The settings used for PCR amplification of microsatellite regions consisted of: one cycle of $94{ }^{\circ} \mathrm{C}$ for $3 \mathrm{~min}$.; 35 cycles of $94{ }^{\circ} \mathrm{C}$ for $30 \mathrm{sec}$.; pairing primer temperature for $30 \mathrm{sec}$. at $72{ }^{\circ} \mathrm{C}$; and a final cycle at $72{ }^{\circ} \mathrm{C}$ for $5 \mathrm{~min}$. The reactions of amplification were performed in thermocyclers 9600 and 9700 (Applied Biosystems). Products of the amplification were diluted and then mounted in a multiplex of two and three distinct amplified loci (Brandoni \& Grattapaglia 2001). The multiplex loci were then denatured at $94{ }^{\circ} \mathrm{C}$ for 5 minutes and submitted to capillary electrophoresis in ABI Prism 3700 machine (Applied Biosystems).

The mating system analyses were based on the mixed mating model (Ritland \& Jain 1981) and correlated mating model (Ritland 1989). Estimates were obtained using the MLTR program (Ritland 2002) and the method of maximum likelihood (Expectation Maximization algorithm). The estimated parameters were: population multilocus outcrossing rate $\left(t_{m}\right)$; single locus outcrossing rate $\left(t_{s}\right)$; outcrossing rate between related individuals $\left(t_{m}-t_{s}\right)$; the effective rate of crossing between relatives for dioecious species $\left(1-t_{s}\right.$ or $1-t_{m}$, depending on which estimate is the lowest, $t_{s}$ or $\left.t_{m}\right)$; multilocus paternity correlation $\left(r_{p(m)}\right)$; and the difference between multilocus and single locus paternity correlation $\left(r_{p(s)}-r_{p(m)}\right) .95 \%$ confidence intervals of the estimates were obtained using 1000 bootstraps and the resampling unit used was the family. The mating system parameters were used to estimate other ecological and genetic parameters, such as the effective number of pollen donors $\left(\hat{N}_{e p}=1 / \hat{r}_{p(m)}\right)$ and average coancestry coefficient $(\Theta)$ within families. Average coancestry within families was estimated using the expression for dioecious species that present mating among relatives:

$$
\begin{aligned}
& \hat{\Theta}=0,125 \hat{t}_{s}\left(1+\hat{F}_{p}\right)\left(1+\hat{r}_{p}\right)+0,25\left(1-\hat{t}_{s}\right)\left[2 \hat{t}_{s}\left(1+\hat{F}_{p}+2 \hat{\theta}_{p}\right)+\right. \\
& \left.+\hat{t}_{s}\left(1+\hat{F}_{p}+6 \hat{\theta}_{p}\right)\left(1-\hat{r}_{p(m)}\right)\right]+0,125\left(1-\hat{t}_{s}\right)^{2}\left[\left(1+\hat{F}_{p}+6 \hat{\theta}_{p}\right)\right. \\
& \left.\left(1-\hat{r}_{p(m)}\right)+\left(1+\hat{F}_{p}+2 \hat{\theta}_{p}\right) 2 \hat{r}_{p(m)}\right]
\end{aligned}
$$

where $F_{p}$ is the estimate of the inbreeding coefficient in the parental population; and $\theta_{p}$ is the estimate of the coancestry coefficient in the parental generation, assumed to be 0.125 (ranging from 0.0625 to 0.25 ).

Additionally, to understand genetic representation within progenies we estimated the effective population size $\left(N_{e(v)}\right)$ : $\hat{N}_{e(v)}=0,5 /\left\{\hat{\Theta}[(n-1) / n]+\left(1+\hat{F}_{o}\right) / 2 n\right\}$ (Cockerham 1969), where $n$ is the sample size and $F_{o}$ is the coefficient of inbreeding in progenies $\left(F_{o}=0\right.$, according to Gaino et al. 2010). The number of seed trees $(m)$ necessary for seed collection was calculated with the goal of retaining the effective reference sample size of 150 , as has been suggested by Nunney \& Campbell (1993): $\hat{m}=N_{\text {e(referenciav) }} / \hat{N}_{e(v)}$ (Sebbenn 2006). The latter expression is based on two assumptions: i) the seed trees from which seeds were collected are not related; and ii) the seed trees do not receive an overlapping pollen gene pool. It is important to remark that the reference sample size of 150 was selected because Nunney \& Campbell (1993) have pointed that the classical reference sample size of 50 (short term or 10 generations) and 500 (long term or 100 generations), suggested by Frankel and Soulé (1981) were derived for species without overlapping generation (for example, annual species). However, in species with overlapping generations as trees, the inbreeding may increase faster than in annual species, and thus, Nunney \& Campbell (1993) have suggested multiply the classical Frankel and Soulé (1981) values (50 or $500)$ for 3 to 10 times. Thus, here it was opted to multiply by three times, $150(3 \times 50)$.

\section{Results}

The population multilocus outcrossing rate $\left(t_{m}\right)$ was not significantly different from 1.0 (table 1 ). The single locus outcrossing rate $\left(t_{s}\right)$ was significantly lower than the multilocus outcrossing rate (table 1). The difference between multilocus and single locus outcrossing rate $\left(1-t_{s}\right)$, although low, was significantly different from zero (table 1), suggesting mating among relatives. The multilocus paternity correlation $\left(r_{p(m)}\right)$ was significantly different from zero for average populations (table 1), indicating that families are composed of mixtures of half-sibs and full-sibs. Therefore, $14.7 \%$ of the individuals within families were full-sibs. The difference between multilocus and single locus outcrossing correlation of paternity $\left(r_{p(s)}-r_{p(m)}\right)$, which measures the occurrence of related pollen donors was significantly different 
Table 1. Estimates of mating system parameters in a Myracrodruon urundeuva population.

\begin{tabular}{ll}
\hline Parameters & Paulo de Farias-SP $(95 \%$ CI $)$ \\
\hline Multilocus outcrossing rate: $t_{m}$ & $1.000(1.000-1.000)$ \\
Single locus outcrossing rate: $t_{s}$ & $0.980(0.979-0.990)$ \\
Effective mating among relatives: $1-t_{s}$ & $0.020(0.010-0.021)$ \\
Multilocus paternity correlation: $r_{p(m)}$ & $0.148(0.093-0.173)$ \\
Effective number of pollen donors: $N_{e p}$ & $6.8(5.8-10.7)$ \\
Coancestry within families: $\Theta$ & $0.147(0.138-0.154)$ \\
Relatedness within families: $r_{x y}$ & $0.294(0.276-0.308)$ \\
Variance effective population size: $N_{e(v)}$ & $2.98(2.87-3.15)$ \\
Number of seed trees for seed collection: $m$ & $50(48-52)$ \\
\hline
\end{tabular}

Where $m$ is the number of seed trees from which it is necessary to collect seeds in order to obtain a sample with an effective population size of $150(3 \times 50$, Nunney \& Campbell 1993).

from zero. The effective number of pollen donors was estimated at 6.67 (table 1). The coancestry coefficient within families $(\Theta)$ was higher and the variance effective population size $\left(N_{e(v)}=2.98\right)$ was lower than expected in half-sib families $\left(\Theta=0.125, N_{e(v)}=4\right.$, respectively). Therefore, to obtain seed lots with an effective population size of 150 , it is necessary to collect seeds from at least 50 seed trees.

\section{Discussion}

The estimated population multilocus outcrossing rate reaffirmed that $M$. urundeuva is a dioecious species. Estimates of outcrossing rate equal to unity have also been obtained for other Brazilian dioecious tree species, such as Araucaria angustifolia (Bertol.) Kuntze (Sousa et al. 2005). Studies in the dioecious tree Ilex paraguariensis A. St-Hil. (Wendt et al. 2009) and Bagassa guianensis Aubl. (Silva et al. 2008) observed outcrossing rates lower than unity. The authors attributed these results to the occurrence of mating among related individuals.

Our results confirmed the occurrence of mating among relatives in the EEPF population. As the species is dioecious, this result indicates the presence of related male and female individuals in the populations, also observed by Gaino et al. (2010) studying seed and pollen dispersal in the same population. Genetic and ecological factors such as intrapopulation spatial genetic structure (SGS) and gene flow, can contribute to the occurrence of mating among relatives. The EEPF population has a strong SGS (up to approximately $45 \mathrm{~m}$ ) and one study indicated that a significant proportion (between 28 to $58 \%$ ) of the pollen was dispersed over short distances, up to $100 \mathrm{~m}$ (Gaino et al. 2010). A SGS associated with a predominant pattern of short-distance pollen dispersed explains the occurrence of mating among relatives in the population. Biparental inbreeding produces inbreeding depression (Sebbenn 2006). For small populations of tropical tree species, a rapid increase of inbreeding is a problem because it increases the homozygosity of deleterious recessive alleles (Falconer \& Mackay 1996). In contrast, in large heterozygous populations natural selection ensures these alleles continue to be rare (Falconer \& Mackay 1996). Finally, mating among relatives has also been observed for other tree species, with values of $t_{m}-t_{s}$ ranging from 0.01 in Hevea brasiliensis (Willd. ex A. Juss.) Müll. Arg. (Furlani et al. 2005) to 0.30 in Hymenaea stigonocarpa Mart. ex Hayne (Moraes et al. 2007).

In terms of seed collection for conservation programs, we should avoid using inbred seeds because it can result in high mortality in plantations and lead to increased cost due to the need for replanting (Sebbenn 2006). As conservation programs use open-pollinated seeds, the only way to get around the problem of inbreeding is to carefully select plants in the nursery, excluding albinos or those with slow growth or malformation. From a genetic conservation standpoint, inbreeding resulting from mating among relatives may compromise the long-term survival of individuals. For this population, dense vegetation and isolation of the fragment (Gaino et al. 2010), are likely affecting not only the population of M. urundeuva, but the entire community of tree species present in EEPF as well. Despite the significant extension of the forest fragment, it is evident that the absence of links between fragments may endanger the survival of many tropical tree species.

The results of the correlated mating analysis suggest that there is a non-random mating pattern in the population. However, the proportion of half-sibs (about 85\%) was substantially higher than full-sibs, indicating a high frequency of random mating. Similar 
results were reported in other insect pollinated dioecious tree species, such as Bagassa guianensis $\left(r_{p(m)}=0.140\right.$, Silva et al. 2008), as well as in the monoecious trees, Caryocar brasiliensis Cambess. $\left(r_{p(m)}=0.160\right.$, Collevatti et al. 2001) and Cedrela odorata L. $\left(r_{p(m)}=0.160\right.$, James et al. 1998). Correlated mating may be explained by flowering asynchrony, small population size and the foraging behavior of pollinators systematically visiting near neighbor trees (Sebbenn 2006). Nunes et al. (2008) studying the ecological aspects related to the phenology of M. urundeuva, noted that their reproduction is directly influenced by temperature and precipitation. The authors also mentioned that the reproductive phase of the species is limited (two months) and restricted to the dry season. Additionally, according to Mantovani \& Martins (1988), environmental factors, particularly rainfall, may affect the movement of pollinators; plant species can in turn develop mechanisms to respond to environmental stimuli. Aspects of the phenology, along with the features of the biology of the species, may favor the occurrence of some non-random mating among individuals, as already reported for other tropical tree species (James et al. 1998, Collevatti et al. 2001, Lacerda et al. 2008, Silva et al. 2008).

From the estimate of paternity correlation it is possible to estimate the effective number of pollen donors $\left(N_{e p}\right)$ that pollinated the seed trees (Ritland 1989). Our result for the M. urundeuva population was relatively high $\left(\hat{N}_{e p}=6.8\right)$ in comparison with the average number of pollen donors found in other animal pollinated tropical tree species $\left(\hat{N}_{e p}=3\right.$, Sebbenn 2006). However, similar values were observed for the dioecious Bagassa guianensis $\left(\hat{N}_{e p}=7.1\right.$, Silva et al. 2008$)$ and the self-incompatible and bat pollinated Hymenaea courbaril L. $\left(\hat{N}_{e p}=6.3\right.$, Lacerda et al. 2008). Three factors may explain the observed high number of effective pollen donors in the M. urundeuva population: i) the relatively large population size (470 trees); ii) fruits bearing a single seed; and iii) the probably large number of bees pollinating the trees.

Information regarding mating among relatives and correlated matings is extremely important for conservation genetics, forest improvement activities and the collection of seeds for reforestation programs (Moraes \& Sebbenn 2011). Ecological processes affect the number of seed trees required for seed collection, due to increase in the frequency of identical by descent alleles (Sebbenn 2006). The observed combination of mating among relatives and correlated mating increases the coancestry and decreases the effective population size within families. In an idealized population (infinite size, random mating, no selection, mutation and migration) the variance effective population size within families corresponds to four unrelated and non-inbred individuals. However, deviations from the assumptions that characterize the idealized population cause reduction in the variance effective population size. Far from being an ideal population, the progenies of the EEPF population had a smaller effective population size than that expected for panmictic populations. In fact, deviations from random mating patterns have been observed in several other studies of tropical species. According to the results observed in this study, seed collection programs for environmental restoration, conservation genetics and breeding programs using germplasm from the EEPF M. urundeuva population, should collect seeds from at least 50 seed trees to retain the effective sample size of 150 . According to the results obtained by Gaino et al. (2010) who observed spatial genetic structure in the population, we stress the need to maintain a distance between sampled trees of at least $100 \mathrm{~m}$ to avoid collecting seeds from related seed trees. Seeds collected from related trees will reduce the effective size of the progeny arrays. The determined number of seed trees (50) necessary for seed collection is lower than has been recommended for other tropical tree species ( $m=67$, Sebbenn 2006) as M. urundeuva does not present selfing and the rate of correlated mating was relatively low (15\%).

The results of this study provide important information about the mating system of the M. urundeuva. Such analyses can be used to enhance conservation strategies and inform seed collection strategies for environmental reforestation programs. Despite the isolation of the EEPF forest fragment (Gaino et al. 2010), it represents an important collection of germplasm to be used in the conservation of not only M. urundeuva, but the entire flora population present within the area. However, links to other forest fragments are essential for its in situ conservation, thus ensuring the survival of the remaining forest for future generations.

Acknowledgements - This project was suported by funding from the Fundação de Amparo à Pesquisa no Estado de São Paulo (Fapesp). The authors thank Coordenação de Aperfeiçoamento de Pessoal de Nível Superior (Capes) for the PhD scholarship provided to Ana Paula Silva Campos Gaino. For help in completing field work, we thank to José Cambuim, Alonso A. da Silva and Manoel F. R. Bonfim from Fazenda de Ensino e Pesquisa of UNESP, Campus de Ilha Solteira, and Aparecido D. T. Maia, Adalto R. Souza, Dirceu A. Machado, Josimar D. Lima, and Valdereci F. Meireles do of the Instituto Florestal. We also thank two reviewers and Evelin R. Nimmo for improvements. 


\section{Bibliographic references}

BAWA, K.S. 1974. Breeding systems of tree species for a lowland tropical community. Evolution 28:85-92.

BAWA, K.S., PERRY, D.R. \& BEACH, J.H. 1985. Reproductive biology of tropical lowland rain forest trees. I. Sexual systems and incompatibility mechanisms. American Journal of Botany 72:331-345.

BRONDANI, R.P.V. \& GRATTAPAGLIA, D. 2001. A simple and cost effective method to synthesize a fluorescent labeled internal DNA standard for fragment sizing in an automatic sequencer. Biotechniques 31 : 793-800.

CAETANO, S., SILVEIRA, P., SPICHIGER, R. \& NACIRIGRAVEN, Y. 2005. Identification of microsatellite markers in a neotropical seasonally dry forest tree, Astronium urundeuva (Anacardiaceae). Molecular Ecology Notes 5:21-23.

CARVALHO, P.E.R. 1994. Espécies florestais brasileiras: recomendações silviculturais, potencialidade e uso da madeira. Embrapa-CNPF, Colombo.

COCKERHAM, C.C. 1969. Variance of gene frequencies. Evolution 23:72-84.

COLLEVATTI, R.G., GRATTAPAGLIA, D. \& HAY, J.D. 2001. Population genetic structure of the endangered tropical tree species Caryocar brasiliense, based on variability at microsatellite loci. Molecular Ecology 10:349-356.

DOYLE, J.J. \& DOYLE, J.L. 1990. Isolation of plant DNA from fresh tissue. Focus 12:13-15.

FALCONER, D.S. \& MACKAY, T.F.C. 1996. Introduction to quantitative genetics. $4^{\text {th }}$ ed., Longman Scientific \& Technical, London.

FIGUEIRÔA, J.M., BARBOSA, D.C.A. \& SIMABUKURO, E.A. 2004. Crescimento de plantas jovens de Myracrodruon urundeuva Allemão (Anacardiaceae) sob diferentes regimes hídricos. Acta Botanica Brasilica 18:573-580.

FRANKEL, O.H. \& SOULÉ, M.S. 1981. Conservation and evolution. Cambridge University Press, Cambridge.

FURLANI, R.C.M., MORAES, S.B., MORAES, M.L.T., PAIVA, J.R. \& SEBBENN, A.M. 2005. Mating system in natural population of Hevea brasiliensis by allozimes. Crop Beeding and Appplied Biothecnology 5:402-409.

GAINO, A.P.S.C., SILVA, A.M., MORAES, M.A., ALVES, P.F., MORAES, M.L.T.M., FREITAS, M.L.M.F. \& SEBBENN, A.M. 2010. Understanding the effects of isolation on seed and pollen flow, spatial genetic structure and effective population size of the dioecious tropical tree Myracrodruon urundeuva. Conservation Genetics 11:1631-1643.

JAMES, T., VEGE, S., ALDRICH, P. \& HAMRICK, J.L. 1998. Mating systems of three tropical dry forest tree species. Biotropica 30:587-594.
JENNERSTEN, O. 1988. Pollination in Dianthus deltoides (Caryophyllaceae): effects of habitat fragmentation on visitation and seed set. Conservation Biology 2:359-366.

LACERDA, A.B., SEBBENN, A.M. \& KANASHIRO, M. 2008. Long-pollen movement and deviation of random mating in a low-density continuous population of Hymenaea courbaril in the Brazilian Amazon. Biotropica 40:462-470.

LORENZI, H. 1998. Árvores brasileiras: manual de identificação e cultivo de plantas arbóreas do Brasil. Plantarum, Nova Odessa.

LOVELESS, M.D. \& HAMRICK, J.L. 1984. Ecological determinants of genetic structure in plant populations. Annual Review of Ecology and Systematics 15:65-95.

LOWE, A.J., BOSHIER, D., WARD, M., BACLES, C.F.E. \& NAVARRO, C. 2005. Genetic resource impacts of habitat loss and degradation; reconciling empirical evidence and predicted theory for Neotropical trees. Heredity 95:255-273.

MANTOVANI, W. \& MARTINS, F.R. 1988. Variáveis fenológicas das espécies do cerrado da Reserva Biológica de Moji Guaçu, Estado de São Paulo. Revista Brasileira de Botânica 11:101-112.

MENGES, E.S. 1991. Seed germination percentage increases with population size in a fragmented prairie species. Conservation Biology 5:158-164.

MORAES, M.L.T. \& SEBBENN, A.M. 2011. Pollen dispersal between isolated trees in the Brazilian savannah: a case study of the Neotropical tree Hymenaea stigonocarpa. Biotropica 40:462-470.

MORAES, M.L.T., KAGEYAMA, P.Y. \& SEBBENN, A.M. 2007. Sistema de reprodução em pequenas populações fragmentadas e em árvores isoladas de Hymenaea stigonocarpa. Scientia Forestalis 74:75-86.

NASON, J.D. \& HAMRICK, J.L. 1997. Reproductive and genetic consequences of forest fragmentation: two case studies of Neotropical canopy trees. Journal of Heredity 88:264-276.

NOGUEIRA, J.C.B., SIQUEIRA, A.C.M.F., MORAES, E., COELHO, L.C.C., MARIANO, G., KAGEYAMA, P.Y., ZANATTA, A.C. \& FIGLIOLIA, M.B. 1982. Conservação genética de essências nativas através de ensaios de progênie/procedências. Silvicultura em São Paulo 16:957-969.

NUNES, Y.R.F., FAGUNDES, M., ALMEIDA, H.S. \& VELOSO, M.D.M. 2008. Aspectos ecológicos da aroeira (Myracrodruon urundeuva Allemão - Anacardiaceae): fenologia e germinação de sementes. Revista Árvore 32:233-243.

NUNNEY, L. \& CAMPBELL, K.A. 1993. Assessing minimum viable population size: demography meets population genetics. Trends in Ecology and Evolution 8:234-239.

PULLIAM, H.R. 1988. Sources, sinks and population regulation. American Naturalistic 132:652-661. 
RIBEIRO, J.H. 1989. Aroeira: durável além de uma vida. Globo Rural 5:85-90.

RITLAND, K. 1989. Correlated matings in the partial selfer Mimulus guttatus. Evolution 43:848-859.

RITLAND, K. 2002. Extensions of models for the estimation of mating systems using $n$ independent loci. Heredity 88:221-228.

RITLAND, K. \& JAIN, S. 1981. A model for the estimation of outcrossing rate and gene frequencies using independent loci. Heredity 47:35-52.

RIZZINI, C.T. 1995. Árvores e madeiras úteis do Brasil: manual de dendrologia brasileira. 2a ed., Edgard Blocher, São Paulo.

SANTIN, D.A. \& LEITÃO FILHO, H.F. 1991. Restabelecimento e revisão taxonômica do gênero Myracrodruon Freire Alemão (Anacardiaceae). Revista Brasileira de Botânica 14:133-145.

SEBBENN, A.M. 2006. Sistema de reprodução em espécies arbóreas tropicais e suas implicações para a seleção de árvores matrizes para reflorestamentos ambientais. In Pomares de sementes de espécies nativas (A.R. Higa \& L. Silva, eds.). Fundação de Pesquisas Florestais do Paraná - Fupef, Curitiba, p.193-138.
SILVA, M.B., KANASHIRO, M., CIAMPI, A.Y., TOMPSON, I. \& SEBBENN, A.M. 2008. Genetic effects of selective logging and pollen gene flow in a low-density population of the dioecious tropical tree Bagassa guianensis in the Brazilian Amazon. Forest Ecology and Management 255:1548-1558.

SQUILLACE, A.E. 1974. Average genetic correlations among offspring from open-pollinated forest trees. Silvae Genetica 23:149-156.

SOUSA, V.A., SEBBENN, A.M., HATTEMER, H. \& ZIEHE, M. 2005. Correlated mating in populations of a dioecious Brazilian conifer, Araucaria angustifolia (Bert.) O. Ktze. Forest Genetics 12:107-119.

STRANGHETTI, V. 1996. Levantamento florístico das espécies vasculares de uma floresta estacional no norte do Estado de São Paulo, Estação Ecológica de Paulo de Faria. Tese de doutorado, Universidade Estadual de Campinas, Campinas.

WENDT, S.N., SOUSA, V.A., M. QUOIRIN, M., MAZZA, M.C., STURION, J.A. \& SEBBENN, A.M. 2009. Baixa taxa de contaminação de pólen, desvios de cruzamentos aleatórios e endogamia em um pomar de sementes de Ilex paraguariensis St. Hil. Scientia Forestalis 37:185-150. 